\title{
Dissection of Predominant Sectors in NIFTY 50
}

\author{
J. Justin Rayappa, Caroline Clement
}

\begin{abstract}
This study pertains to an overall analysis of different sectors in NIFTY 50 in terms of its Risk, Stationary, Volatility, Clustering effect \& Impact of major events on NIFTY 50. Thus, it would predominantly aid the Investors, Portfolio managers \& Researchers while carrying on their market exploration activity with respect to NIFTY 50. In the normal course of business operation in any stock exchange, Risk \& Volatility of stock prices are found to go hand in hand \& thus positioning them as the major influential factors while making investment decisions by the market participants.
\end{abstract}

Keywords : NSE, NIFTY50, ADF, GARCH, ARCH, Major Events. JEL Classification: C01, C22, F32, G11, G15, G20

\section{INTRODUCTION}

A Stock market is the heart of any economy, be it a developing or a developed one. From the economy point of view, a healthy stock market has been considered requisite for economic growth and is anticipated to contribute to improvements in productivity.

India is considered as one of the fastest emerging markets in the world. The stock exchanges in India have an important role to play in building up of real shareholder democracy. The stock exchange authorities aspire to prevent the fraudulent acts of corporate, thus ensures clearness. Both BSE \& NSE follow the same trading mechanism, trading hours, settlement process, etc. There are some risks which are within the control of the investor, but a few are beyond imagination.

\section{OBJECTIVE}

- To analyze the quantum of risk across major sectors in NIFTY 50.

- To probe into the stationary of share prices across sectors.

- To ascertain which sector has more impact on NIFTY 50.

- To examine the volatility \& clustering effect in each sector.

- To investigate the impact of recent events on NIFTY 50.

\section{RESEARCH METHODOLOGY}

The study is entirely based on secondary data and it's purely

Revised Manuscript Received on December 05, 2019.

* Correspondence Author

Dr. J. Justin Rayappa*, Assistant Professor, Department of Commerce, Loyola College, Chennai, India

Caroline Clement, Research Scholar, Department of Commerce, Loyola College, Chennai, India. empirical. The study is carried out with intent to make a dissection analysis of seven major corporate ventures listed in National Stock Exchange and they are as follows;

- Dr. Reddy.

- TCS.

- HERO MOTORS.

- RELIANCE.

- ULTRATEC CEMENT.

- HDFC

- HUL.

The return on closing price was calculated as: $\mathrm{R} t=\log (\mathrm{Pt})$ $-\log (\mathrm{Pt}-1)$.

Where $\mathrm{R} \mathrm{t}$ is a daily closing price at time $\mathrm{T}, \mathrm{Pt}$ denotes the closing price of the company at time period $\mathrm{T}$ and $\mathrm{P} \mathrm{t}-1$ denotes the closing price of the company at time period T-1. The methodology/design for this research work is as follows;

$>$ Descriptive Analysis.

$>$ Unit Root Test - ADF Test.

> Regression Analysis - The least square method.

> Auto-Regressive Moving Average Method.

$>$ GARCH models.

$>$ Event Study Analysis.

"Eviews 10" statistical software package was used for performing the above econometrics analysis. The study framework spans over a period of 5 years starting from 1 st February 2014 till 31st January 2019 involving around 9856 number of data points, which provide rich data set for analysis. The reason for specifically choosing this study period is to conduct research work in an updated timeframe so that it would be more reliable.

\section{LITERATURE REVIEW}

Pandey (2002) concluded that in India, the stock market is helpful for investors even for sharing investments to earn their abnormal returns as it is not informationally efficient, as the price does not always incorporate all the available information.

Poon \& Granger (2003) submitted a study that volatility had wide sphere of control. Major influences include investment, valuation of security, policy making and risk management. The importance of volatility forecasting in various areas like financial risk management, options pricings, etc. were also emphasized.

Batra (2004) in his study examined the economic importance of changes in the pattern of stock market volatility in India during the years 1979 to 2003 . The study

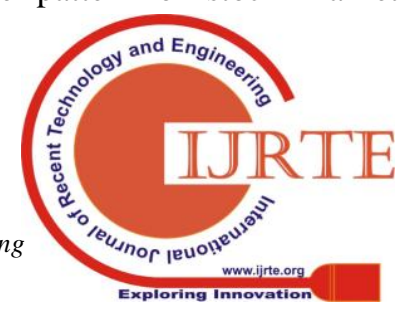




\section{Dissection of Predominant Sectors in NIFTY 50}

reveals that the nearly all volatile period in the stock market was the period around the BOP crisis and beginning of the

economic reforms in India during that crisis.

\section{EMPIRICAL RESULTS}

\section{QUANTUM OF RISK ACROSS MAJOR SECTORS IN NIFTY 50.}

Table 1

Source: Author's calculation

\begin{tabular}{|c|c|c|c|c|c|c|c|}
\hline & ULTRATEC & TCS & RELIANCE & REDDY & HUL & HEROMOT & HDFC \\
\hline Mean & 0.000608 & 0.000621 & 0.000957 & $6.03 E-05$ & 0.000988 & 0.000341 & 0.001005 \\
\hline Median & 0.000330 & 0.000426 & 0.000548 & 0.000197 & 0.000176 & $-2.21 \mathrm{E}-05$ & 0.000619 \\
\hline Max & 0.075163 & 0.064115 & 0.104027 & 0.092860 & 0.080920 & 0.069850 & 0.052212 \\
\hline Min & -0.077186 & -0.09264 & -0.090306 & -0.157366 & -0.05291 & -0.064678 & -0.04062 \\
\hline Std. Dev. & 0.016654 & 0.014465 & 0.015849 & $\mathbf{0 . 0 1 8 1 2 6}$ & 0.013578 & 0.015153 & 0.010574 \\
\hline Skewness & 0.022369 & $\mathbf{- 0 . 2 2 3 0 3}$ & 0.040531 & $\mathbf{- 0 . 7 5 1 9 8 8}$ & 0.329248 & 0.210614 & 0.367902 \\
\hline Kurtosis & 4.553016 & 5.794223 & 6.055336 & $\mathbf{1 0 . 5 9 6 1 1}$ & 5.004331 & 4.989177 & 4.776065 \\
\hline
\end{tabular}

\section{AUGMENTED DICKEY-FULLER UNIT ROOT TEST}

The ADF null hypothesis is established as a unit root in the time series, and the alternative is - there is no unit root, and it is stationary.

Table 2

\begin{tabular}{|l|c|c|c|c|}
\hline & \multicolumn{2}{|c|}{ at level } & \multicolumn{2}{c|}{ 1st difference } \\
\hline & t-statistics & probability & t-statistics & probability \\
\hline 1. Dr. Reddy. & -2.135432 & 0.2308 & -31.31658 & 0.0000 \\
\hline 2. TCS. & -0.008672 & 0.9566 & -33.77762 & 0.0000 \\
\hline $\begin{array}{l}\text { 3. HERO } \\
\text { MOTORS. }\end{array}$ & -2.178661 & 0.2144 & -32.6787 & 0.0000 \\
\hline 4. RELIANCE. & 0.364343 & 0.9814 & -32.90639 & 0.0000 \\
\hline $\begin{array}{l}\text { 5. ULTRATEC } \\
\text { CEMENT. }\end{array}$ & -2.442613 & 0.1303 & -33.28419 & 0.0000 \\
\hline 6. HDFC. & -0.514519 & 0.8858 & -27.04021 & 0.0000 \\
\hline 7. HUL. & 0.472534 & 0.9858 & -36.82447 & 0.0000 \\
\hline
\end{tabular}

INTERPRETATION: - From the above table it is interpreted that the entire time series are non-stationary at its level for all the seven companies. The calculated value of probability is less than 0.05 or $5 \%$ level of significance. Hence null hypothesis is accepted, which indicates that all the series are stationary. Therefore each series data is integrated in order 1 .

\section{SECTOR WISE IMPACT ON NIFTY 50.}

Dependent Variable: DLOG(NIFTY_50)

Method: Least Squares

Date: 03/06/19

Sample (adjusted): 2/04/2014 10/23/2018
Included observations: 1231 after adjustments

Table 3

\begin{tabular}{|l|c|c|c|c|}
\hline \multicolumn{1}{|c|}{ Variable } & Coefficient & Std. Error & t-Statistic & Prob. \\
\hline C & -0.000192 & 0.000121 & $\begin{array}{c}-1.59374 \\
4\end{array}$ & 0.1113 \\
\hline DLOG(DR_REDDY) & 0.048639 & 0.006764 & 7.190537 & 0.0000 \\
\hline DLOG(HDFC) & 0.277536 & 0.012941 & 21.44704 & 0.0192 \\
\hline DLOG(HEROMOTORS) & 0.095754 & 0.00867 & 11.04428 & 0.0000 \\
\hline DLOG(HUL) & 0.069091 & 0.009291 & 7.436689 & 0.0068 \\
\hline DLOG(RELIANCE) & 0.160313 & 0.008416 & 19.04868 & 0.0095 \\
\hline DLOG(TCS) & 0.093095 & 0.008455 & 11.01006 & 0.0268 \\
\hline DLOG(ULTRATEC) & 0.127866 & 0.008082 & 15.82022 & 0.0000 \\
\hline
\end{tabular}

\begin{tabular}{|c|c|c|c|}
\hline R-squared & 0.753226 & Mean dependent var & 0.00048 \\
\hline Adjusted R-squared & 0.751813 & S.D. dependent var & 0.008434 \\
\hline S.E. of regression & 0.004202 & Akaike info criterion & -8.10024 \\
\hline Sum squared resid & 0.02159 & Schwarz criterion & -8.067 \\
\hline Log likelihood & 4993.698 & Hannan-Quinn criter. & -8.08773 \\
\hline F-statistic & 533.2783 & Durbin-Watson stat & 2.073897 \\
\hline Prob(F-statistic) & 0 & & \\
\hline
\end{tabular}

Interpretation: - As per the above table, $\mathrm{R}$ - square value is nearly 0.075 or $75 \%$ which implies that our major seven companies closing price have a strong impact on the National Stock Exchange Index (NIFTY 50) and it's significant at 5\% level. Among those major seven companies HDFC bank has more impact on NIFTY 50.

\section{VOLATILITY\& CLUSTERING EFFECT ACROSS SECTORS}


Table 4

\begin{tabular}{|c|c|c|c|c|c|}
\hline COMPANY & VARIABLE & COEFFEICENT & STD.ERROR & Z-STATISTIC & PROB. \\
\hline \multirow{2}{*}{ DR.REDDY } & $\operatorname{RESID}(-1)^{\wedge} 2$ & 0.15 & 0.053937 & 2.78103 & 0.0054 \\
\hline & GARCH(-1) & 0.599971 & 0.132394 & 4.531697 & 0 \\
\hline \multirow{2}{*}{ TCS } & $\operatorname{RESID}(-1)^{\wedge} 2$ & 0.149949 & 0.052019 & 2.882573 & 0.0039 \\
\hline & GARCH(-1) & 0.599949 & 0.135873 & 4.4155 & 0 \\
\hline \multirow{2}{*}{ ULTRATEC } & $\operatorname{RESID}(-1)^{\wedge} 2$ & 0.149893 & 0.031517 & 4.756008 & 0 \\
\hline & GARCH(-1) & 0.599893 & 0.080567 & 7.445852 & 0 \\
\hline \multirow{2}{*}{ HUL } & $\operatorname{RESID}(-1)^{\wedge} 2$ & 0.149932 & 0.037197 & 4.03077 & 0.0001 \\
\hline & GARCH(-1) & 0.599932 & 0.088133 & 6.807111 & 0 \\
\hline \multirow{2}{*}{ HERO MOTORS } & $\operatorname{RESID}(-1)^{\wedge} 2$ & 0.149917 & 0.033777 & 4.438382 & 0 \\
\hline & GARCH(-1) & 0.599917 & 0.090814 & 6.605977 & 0 \\
\hline \multirow{2}{*}{ RELIANCE } & $\operatorname{RESID}(-1)^{\wedge} 2$ & 0.15 & 0.084237 & 1.780692 & 0.075 \\
\hline & GARCH(-1) & 0.599875 & 0.220588 & 2.919432 & 0.0065 \\
\hline \multirow{2}{*}{ HDFC } & $\operatorname{RESID}(-1)^{\wedge} 2$ & 0.15 & 0.082401 & 1.820375 & 0.0687 \\
\hline & GARCH(-1) & 0.599971 & 0.253225 & 2.369321 & 0.0178 \\
\hline
\end{tabular}

INTERPRETATION: - The Table 4 shows the ARCH \& GARCH co-efficient \& its probability values are significant at 5\% level, which means there is an Auto- Regressive effect in Dr. Reddy, TCS, Ultratec, HUL and Hero Motors stock price, and thus it implies that the future is influenced by past movements of stock behaviour. GARCH effect shows that there is a strong Volatility \& Clustering effect being found in this data whereas in Reliance and HDFC the co-efficient \& its probability values are not significant at $5 \%$ level, which means there is absence of Auto- Regressive effect in those two company stock price, and thus it implies that the future is not influenced by past movements of stock behaviour. GARCH effect shows that there is a Very High Volatility \& Clustering effect being found in this data.

\section{FINDINGS}

Among the seven companies, Dr. Reddy seems to have high standard deviation, which expresses that the prices of its stocks are more volatile in the market, and thus it exhibits high risk.

The Skewness for the returns series is almost positive other than TCS \& Dr. Reddy, so those data' $s$ are asymmetric in nature. As far as Kurtosis is concerned for these companies, it was found just close to five across all the sectors, except Dr. Reddy which implies that series has a thicker tail compared to a normal distribution.

As per the multiple regression analysis, the $\mathrm{R}-$ square value was nearly 0.075 or $75 \%$ which implies that the closing price of the major seven companies which have been taken up for this study have a strong impact on the National Stock Exchange Index (NIFTY 50) and it's significant at 5\% level. Among those major seven companies HDFC bank has more impact on NIFTY 50.

The investigation of volatility \& clustering effect across the major sectors in NIFTY 50 using GARCH model reveals that, the stock prices of these sectors has a very strong volatility \& clustering effect that is seen in its past, that has

become evident in the course of this study. The ARCH \& GARCH co-efficient \& its probability values are significant at $5 \%$ level, which means there is an Auto- Regressive effect in the stock prices of the sectors except in the stock prices of Reliance \& HDFC, and thus it implies that the future stock price movements of the five sectors is influenced by past movements of stock behaviour.

\section{SUGGESTIONS}

Training programmes for existing investors should be conducted on a regular basis to make them aware of the behaviour of stock market and management of risk through scientific analysis. The present study used only one index Nifty. It could be further extended to the other indices and finding out the relative impacts across stock exchanges round the world would aid the investors to predict the future stock behaviour.

\section{CONCLUSION}

Indian Economy has undergone significant transformation driven by Liberalization and Globalization forces in the past decades. Exponential increases in the pace at which these changes have been made have touched all the sectors of our economy with the Indian Capital market and Indian industry sitting on top of the list. This study has rendered a definite contribution to the existing reservoir of knowledge in the domain of stock market volatility particularly in Indian context.

\section{REFERENCES}

1. https://faculty.iima.ac.in/ jrvarma/papers/WP990705.pdf

2. https://doi.org/10.1108/03074359810765471

3. https://ssrn.com/abstract $=156008$

4. http://www.icrier.org/pdf/wp124.pdf.

5. www.icrier.org/pdj/wp124.pdf.

6. http://www.journaloffinancialmarketsresearch.com.

7. www.indexinvestor.co.za. 


\section{AUTHORS PROFILE}

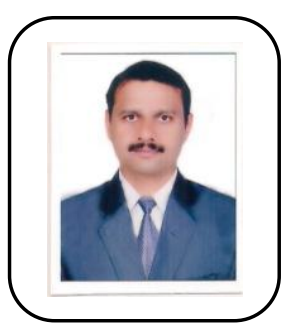

Dr. J. Justin Rayappa, has Doctorate of Philosophy (Commerce) from University of Madras, Master of Philosophy (Commerce) from Madurai Kamaraj Unviersity, Master of Commerce from ST. Joseph's College, Trichy. Books Published \& Edited: Co-Edited the conference proceedings on "Entrepreneurship, Youth \& Inclusive Development for Brand India' organised by Post Graduate and Research Department of Commerce, Loyola College (Autonomous). Enriched and Reviewed a book on "Basics of Money and Money Management" published by National Stock Exchange of India Ltd. (NSE) in collaboration with Tamilnadu Text Book Corporation, Government of Tamil Nadu, India. Authored a book on"Project \& Quality Management" published by Kuvembu University, Shimoga, Karnataka, India in collaboration with International Business Management Studies Educational Trust (ICBMS), Chennai. Authored a book on "Customer Relationship Management" published by Kuvembu University, Shimoga, Karnataka, India in collaboration with International Business Management Studies Educational Trust (ICBMS), Chennai.

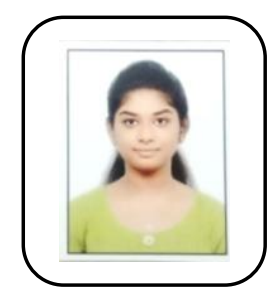

Caroline Clement, has a Masters in Commerce from Stella Maris College, Chennai and currently pursuing Master of Philosophy in Commerce in Loyola College, Chennai. Publications in Journals: Caroline Clement \& Justin Rayappa (2019) “A Study/Analysis On Impact and Effectiveness of Electronic Commerce Strategy On Indian Customers" Infokara, ISSN 1021-9056. Justin Rayappa J \& Caroline Clement (2019) "Investors Fallacy On Continuous Ups Or Down In NIFTY 50" Think India Journal ISSN: 0971-1260, Vol. 22, Issue 10-November-2019. Caroline Clement (2018) "Stealth Marketing Strategy: Challenges" Shanlax International Journal of Commerce, ISSN: 2320-4168, Vol. 6, Special issue:1, pp. 26-30. Carried Research Work on "A Study On Impact of Deceptive Advertisement On Customers' Reaction" for M.Com research project. 